\title{
Perawatan Saluran Akar Satu Kunjungan Pada Pulpa Nekrosis Disertai Restorasi Mahkota Jaket Porselin Fusi Metal dengan Pasak Fiber Reinforced Composit (Kasus Gigi Insisivus Sentralis Kanan Maksila)
}

\author{
Surya Triharsa* dan Ema Mulyawati** \\ * Program Studi Konservasi Gigi PPDGS Fakultas Kedokteran Gigi Univeristas Gadjah Mada \\ *Bagian Konservasi Gigi Fakultas Kedokteran Gigi Univeristas Gadjah Mada \\ *JI Denta No.1 Sekip Utara Yogyakarta, e-mail: suryatriharsa@gmail.com
}

\begin{abstract}
ABSTRAK
Perawatan saluran akar satu kunjungan dapat memperkecil resiko adanya kontaminasi bakteri serta mengurangi jumlah kunjungan. Restorasi gigi insisvus sentralis maksila setelah perawatan saluran akar harus mempertimbangkan sisa jaringan keras gigi yang masih ada. Tujuan laporan kasus ini adalah untuk menginformasikan hasil perawatan saluran akar satu kunjungan dengan restorasi mahkota jaket porselin fusi metal dengan pasak Fiber Reinforced Composit (FRC) pada gigi insisivus sentralis kanan maksila. Pasien perempuan 32 tahun datang ke klinik konservasi Gigi RSGM Prof Soedomo FKG UGM ingin merawat gigi depan atas dengan tumpatan yang telah berubah warna. Berdasarkan pemeriksaan subjektif, objektif dan radiografis diperoleh diagnosis pulpa nekrosis. Selanjutnya dilakukan perawatan saluran akar satu kunjungan, dan restorasi mahkota jaket porselin dengan pasak FRC. Hasil evaluasi klinis saat kontrol tidak ada keluhan rasa sakit gigi dan gigi bisa berfungsi dengan normal. Maj Ked Gi. Juni 2013;20(1): 71 - 77.
\end{abstract}

Kata kunci: Perawatan saluran akar satu kunjungan, Restorasi mahkota jaket porselin fusi metal, pasak fiber reinforced composit.

\begin{abstract}
One Visit Root Canal Treatment On Necrosis Pulp Followed by Fused Porcelain Metal Jacket Crown with Fiber Reinforced Composit (A Case on Right Maxillary Central Incisivus Teeth). One visit root canal treatment is more beneficial to reduce the risk of bacteria and also shorten the time during the treatment in restoring maxillary incisor, considering the on rest of hard tissue. The objective of this case report is to inform the result of restoration teeth 11 to necrotic pulp after one visit root canal treatment. A 32 year-old female came to RSGM Prof Soedomo FKG UGM to have a treatment on her maxillary central teeth restoration for tooth whose color has changed. After an objective and radiograph examination, it was diagnosed that she suffered from necrotic pulp. The treatment chosen was a one visit root canal treatment followed by porcelain fused to metal jacket crown with fiber post reinforced composit. Based on the clinical evaluation, there was no more pain after the treatment, and the aesthetic aspect was also achieved. The patient was satisfied.

Maj Ked Gi. Juni 2013;20(1): 71 - 77.
\end{abstract}

Keywords: one visit endodontic, porcelain fused to metal jacket crown restoration, fiber reinforced composit

\section{PENDAHULUAN}

Karies gigi dapat dialami oleh setiap orang dan dapat timbul pada satu permukaan gigi atau lebih. Karies gigi merupakan suatu penyakit jaringan keras gigi yang melibatkan email, dentin dan pulpa. ${ }^{1}$ Adanya kerusakan gigi pada gigi, baik oleh karena karies maupun trauma dapat berakibat terganggunya fungsi gigi secara maksimal. Kerusakan gigi dapat diawali dengan keradangan pulpa dan bila tidak dilakukan perawatan dapat berlanjut dengan kematian pulpa atau yang dikenal dengan istilah pulpa nekrosis. ${ }^{2}$ 
Gigi yang mengalami nekrosis memerlukan perawatan saluran akar, yang bertujuan untuk membersihkan ruang pulpa dari jaringan pulpa yang telah terinfeksi, kemudian membentuk saluran akar untuk obturasi agar terbentuk apical seal. ${ }^{3}$ Perawatan saluran akar satu kunjungan adalah perawatan saluran akar yang diselesaikan dalam satu kunjungan meliputi pembersihan saluran akar, sterilisasi dan obturasi. ${ }^{4}$ Keuntungan perawatan saluran akar satu kunjungan dapat memperkecil resiko kontaminasi mikroorganisme dalam saluran akar dan mempersingkat kunjungan perawatan saluran akar. ${ }^{2}$

Pada restorasi gigi setelah perawatan saluran akar perlu dipertimbangkan keadaan gigi yang lebih getas, karena kandungan air yang lebih sedikit dibandingkan gigi vital. Perawatan saluran akar seringkali memerlukan pembuangan jaringan keras yang cukup banyak sehingga meninggalkan jaringan keras yang sedikit dan tidak dapat mendukung restorasi dengan baik karena mudah terjadi keretakan atau fraktur. ${ }^{5}$

Apabila marginal ridge pada gigi anterior masih utuh dan hanya kehilangan struktur gigi akibat akses perawatan saluran akar, maka restorasi menggunakan resin komposit merupakan perawatan pilihan. Jika terdapat kavitas tambahan pada gigi tersebut atau jaringan keras gigi banyak yang hilang atau akan hilang pada saat prosedur restorasi, perlu dipertimbangkan penggunaan pasak. ${ }^{6}$ Pasca penggunaan pasak dapat dilanjutkan dengan pembuatan restorasi mahkota jaket porselin fusi metal. Hal ini dapat menjadi pertimbangan karena mahkota jaket porselin fusi metal mempunyai resistensi yang lebih besar dibanding dengan restorasi mahkota jaket porselin karena adanya lapisan logam. ${ }^{5}$ Adanya lapisan logam menjadikan mahkota jaket porselin fusi metal lebih kuat sehingga dapat mengkompensasi sifat rapuh porselin. ${ }^{7}$

Pulpa nekrosis adalah matinya pulpa baik sebagian atau seluruhnya yang dapat terjadi karena inflamasi maupun rangsangan traumatik. Penyebab nekrosis adalah bakteri, trauma, iritasi bahan restorasi maupun inflamasi dari pulpa yang berlanjut. ${ }^{8}$ Pada beberapa kasus, gigi nekrotik diawali dengan riwayat sakit yang berangsur-angsur menjadi nekrosis. ${ }^{9} \mathrm{Gigi}$ dengan pulpa nekrotik tidak selalu menimbulkan gejala rasa sakit. Adanya perubahan warna gigi menjadi keabu-abuan atau kecoklatan seringkali merupakan indikasi kematian pulpa. Apabila ada rangsang panas gigi nekrosis akan terasa sakit karena terjadi pemuaian gas yang akan menekan ujung saraf jaringan vital yang ada disekitarnya, sedangkan dengan rangsang dingin (Chlor Ethyl) dan stimulasi elektrik pada gigi dengan pulpa nekrotik biasanya tidak menimbulkan respon. ${ }^{10}$

Perawatan saluran akar satu kunjungan diindikasikan sebagai berikut : 1) pulpa terbuka karena trauma iatrogenik tanpa lesi periapikal; 2) pulpitis irreversibel tanpa lesi periapikal; 3) gigi nekrosis tanpa gejala-gejala klinis dan lesi periapikal; 4) gigi nekrosis dengan abses periapikal disertai fistula; 5) bentuk saluran akar normal, saluran akar tunggal. Kontra indikasi untuk perawatan saluran akar satu kunjungan adalah: 1) adanya rasa sakit pada gigi nekrosis tanpa disertai fistula untuk drainase; 2) gigi dengan kelainan anatomis yang berat; 3) gigi berakar banyak; 4) periodontitis akut dengan rasa sakit yang parah saat perkusi. ${ }^{6}$ Tujuan perawatan saluran akar satu kunjungan adalah untuk mencegah perluasan penyakit dari pulpa ke jaringan periapikal atau apabila hal tersebut sudah terjadi, bertujuan untuk mengembalikan jaringan periapikal ke keadaan normal. ${ }^{4}$

Keuntungan perawatan saluran akar satu kunjungan antara lain untuk memperkecil resiko kontaminasi mikroorganisme dalam saluran akar, menghemat waktu untuk pera-watan, tidak diperlukan medikasi intrakanal dan tumpatan sementara. " Perawatan saluran akar satu kunjungan menghemat waktu perawatan tanpa mengurangi kualitas dari perawatan. ${ }^{2}$

Gigi yang telah dirawat saluran akar seringkali hanya memiliki sedikit sisa jaringan keras gigi dibagian mahkota sehingga menjadi lebih rapuh dibandingkan gigi vital. Kelembaban yang telah berkurang dan secara klinis lebih mudah fraktur menyebabkan gigi tersebut membutuhkan pasak untuk menahan inti dan restorasi. ${ }^{2}$ Apabila sisa jaringan mahkota gigi masih tersisa dua hingga empat dinding dengan tebal minimum $1 \mathrm{~mm}$ dan tinggi minimum $2 \mathrm{~mm}$ maka tidak diperlukan pasak. ${ }^{13}$ Apabila mengalami 
fraktur vertikal maka biasanya gigi dicabut karena prognosis buruk. Penggunaan pasak dan mahkota jaket porselin fusi metal untuk restorasi gigi anterior ditentukan oleh sisa jaringan gigi yang masih ada, oklusi serta fungsi gigi tersebut. Pemilihan pasak berdasarkan pada kekuatan modulus elastisitas, retensi, biokompatibilitas, estetik dan mudah diperbaiki. Pasak harus kompatibel baik dengan dentin maupun dengan inti yang didukungnya. Bahan yang sering digunakan untuk pasak adalah stainless steel, titanium dan paduannya, porselin serta serat polimer. ${ }^{3}$

Pasak FRC disarankan untuk gigi anterior terutama dengan saluran akar lebar. Pasak ini bersifat estetis, memiliki modulus elastisitas mendekati dentin sehingga dapat mengurangi resiko fraktur akar akibat gaya oblik dan lateral yang diterima gigi, meskipun lokasi sisa mahkota gigi juga mempengaruhi resistensi terhadap fraktur. ${ }^{4}$ Pasak FRC terbuat dari serat berdiameter 7-10 mikrometer dan dikelilingi oleh matriks resin polimer yang umumnya berupa resin epoksi. Bahan inti dan semen resin dapat berikatan dengan pasak jenis ini, bentuk pasak FRC yang paralel lebih retentif dibandingkan dengan pasak taper. ${ }^{14}$ Pasak FRC termasuk pasak pasif dengan konfigurasi permukaan pasak yang rata maupun permukaan pasak yang memiliki groove atau berlekuk untuk menambah retensi. Pada saat dilakukan sementasi tidak memerlukan tekanan pada saluran pasak sehingga mengurangi resiko terjadinya fraktur akar. ${ }^{5}$ Artikel ini bertujuan untuk memaparkan perawatan saluran akar satu kunjungan dengan restorasi mahkota jaket porselin fusi metal dengan pasak Fiber Reinforced Composit (FRC) pada gigi insisivus sentralis kanan maksila

\section{STUDI KASUS}

Pasien wanita berumur 32 tahun, datang ke Klinik Konservasi Gigi Fakultas Kedokteran Gigi Universitas Gajah Mada, ingin mengganti tumpatan gigi depan atas kanan yang telah berubah warna. Pada pemeriksaan objektif diketahui bahwa gigi insisivus sentralis kanan maksila tampak restorasi yang telah berubah warna di bagian palatalnya restorasi tampak menyatu dengan gigi insisivus lateralis kanan maksila yang terletak linguoversi, perkusi negatif, palpasi negatif. Pemeriksaan radiograf terdapat gambaran kavitas yang sudah mencapai kamar pulpa. Diagnosis gigi incisivus sentralis kanan maksila adalah pulpa nekrosis. Prognosis baik dengan pertimbangan saluran akar lurus dan terlihat jelas, sisa jaringan keras gigi masih banyak serta tidak ada keluhan sakit (Gambar 1, 2).

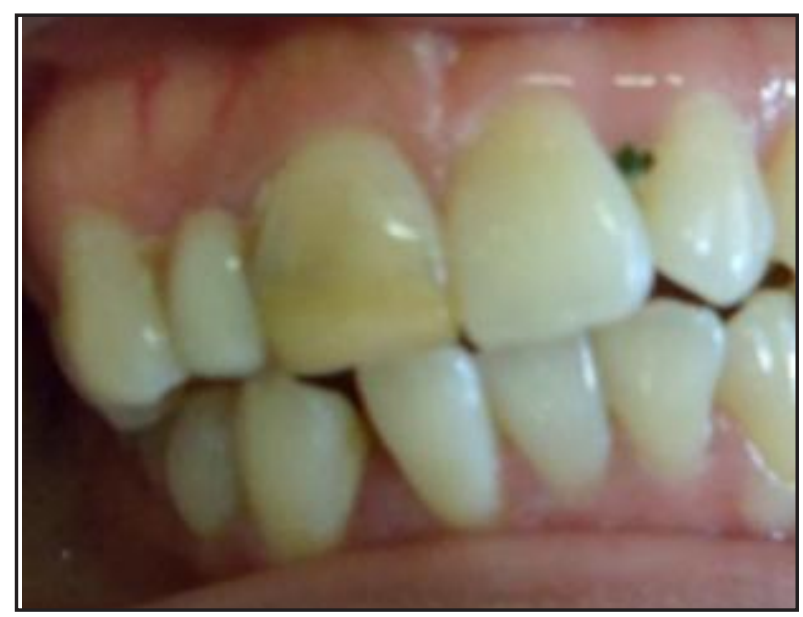

Gambar 1. Gambaran klinis gigi 11

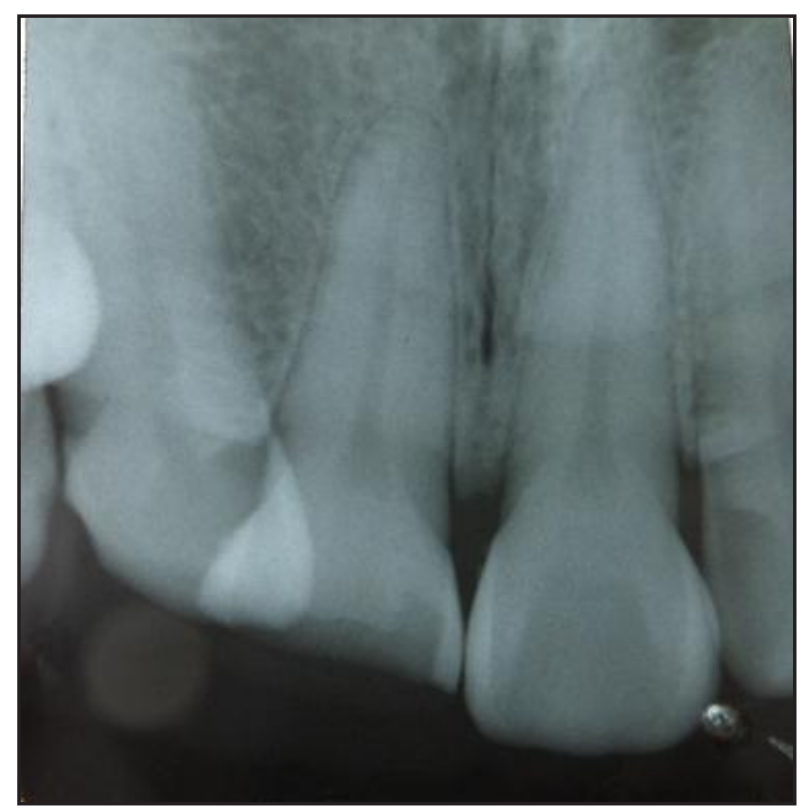

Gambar 2. Radiografis gigi 11

Kunjungan pertama, 24 September 2012 dilakukan pemeriksaan subjektif, pemeriksaan objektif dan radiografis kemudian ditentukan diagnosis dan rencana perawatan. Berdasarkan 
pemeriksaan tersebut maka diagnosis gigi insisvus sentralis kanan maksila adalah nekrosis pulpa. Pasien diberi penjelasan mengenai prosedur rencana perawatan dan biaya serta waktu perawatan. Rencana perawatannya adalah perawatan saluran akar satu kunjungan dan dilanjutkan restorasi mahkota porselin fusi metal dengan pasak fiber prefabricated. Pasien menyetujui tindakan perawatan dan menandatangani informed consent.

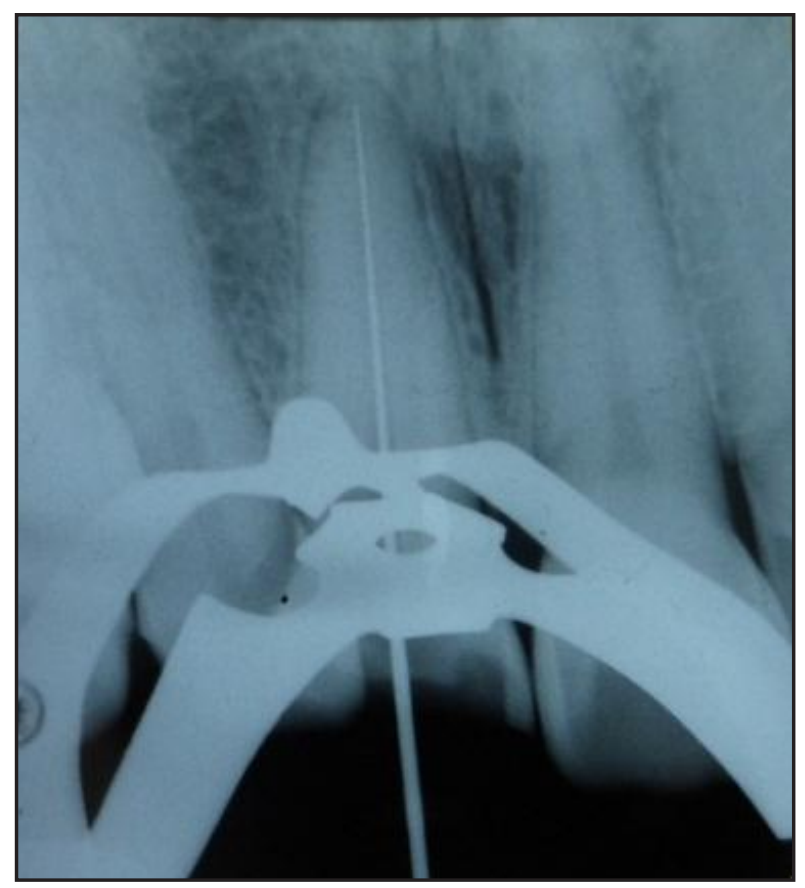

Gambar 3. Radiografis panjang kerja 11

Dilakukan pembukaan akses kavitas menggunakan Endoaccess bur (Dentsply) dan pembukaan atap ruang pulpa dengan bur Diamendo (Dentsply). Saluran akar diirigasi menggunakan $\mathrm{NaOCL} 2,5 \%$ dan keringkan dengan paper point steril. Kemudian dilakukan pengukuran panjang kerja menggunakan foto radiografis dan apexlocator diperoleh panjang kerja 23,5 mm (Gambar 3). Selanjutnya dilakukan eksplorasi dan negosiasi saluran akar menggunakan K-File \#10. K-File dimasukkan ke dalam saluran akar sepanjang $2 / 3$ panjang kerja. Preparasi saluran akar menggunakan teknik step back. Irigasi dilakukan setiap pergantian alat dengan larutan $\mathrm{NaOCl}$ 2,5 \% untuk membersihkan saluran akar dari debris. Initial file (file terbesar yang dapat masuk ke dalam saluran akar sesuai dengan panjang kerja sebelum saluran akar dipreparasi)adalah $\mathrm{K}$-file
\#20. Preparasi apikal diawali menggunakan file \#20 sampai dengan file \#40 sebagai MAF (Master Apical File) dengan panjang kerja 23,5 mm. Setiap penggantian file yang lebih besar, direkapitulasi menggunakan file dengan ukuran satu nomor sebelumnya dan setiap pergantian file dilakukan irigasi menggunakan $\mathrm{NaOCl} 2,5 \%$ sebanyak $2,5 \mathrm{ml}$.

Tahap kedua adalah preparasi badan saluran akar. File yang dipakai sampai dengan 3 nomor lebih besar dari MAF dengan panjang kerja masingmasing dikurangi $1 \mathrm{~mm}$ setiap pergantian ke nomor yang lebih besar. Preparasi badan saluran akar dimulai dari file \#45 PK $22,5 \mathrm{~mm}$, file \#50 PK 21,5 $\mathrm{mm}$ dan file \#55 PK 20,5 mm. Setiap pergantian file dilakukan rekapitulasi dengan file MAF PK 23,5 mm. Setelah preparasi saluran akar dilakukan coronal flaring menggunakan headstroem file \#60 PK $20,5 \mathrm{~mm}$ dan dilakukan finishing dengan file \#40 PK 23,5 mm dengan gerakan sirkumferensial. Setiap pergantian file dilakukan irigasi menggunakan $\mathrm{NaOCl} 2,5 \%$ sebanyak $2,5 \mathrm{ml}$ kombinasi dengan EDTA $15 \%$. Setelah preparasi saluran akar selesai dilakukan irigasi dengan larutan khlorheksidin 2\% dengan cara digenangi selama 30 detik.

Tahap selanjutnya adalah pengepasan gutta percha sesuai MAF dan dilanjutkan dengan pengambilan radiograf (Gambar4). Pengisian saluran akar menggunakan gutta percha dengan teknik kondensasi lateral. Sealer (topseal, dentsply) dimasukkan ke dalam saluran akar menggunakan lentulo yang digerakkan dengan handpiece low speed. Gutta percha utama no. 40 dioleskan sealer pada 1/3 apikal dan dimasukkan ke dalam saluran akar. Spreader dimasukkan di antara gutta percha dan dinding saluran akar, kemudian dilakukan kondensasi kearah apikal. Ruang yang tersedia begitu spreader diangkat diisi dengan gutta percha tambahan dengan ukuran lebih kecil, dan dilakukan kondensasi lagi dengan spreader. Penambahan gutta percha diakhiri sampai spreader tidak dapat masuk lagi ke dalam saluran akar setengah panjang spreader. Gutta percha dipotong sampai batas orifis menggunakan plugger yang dipanaskan dan kemudian dipadatkan. Kavitas ditutup dengan semen fosfat dan tumpatan sementara (orafil G), kemudian dilakukan pengambilan radiograf untuk melihat hasil pengisian saluran akar. Radiograf menunjukkan hasil pengisian yang hermetis (gambar 4 ). 


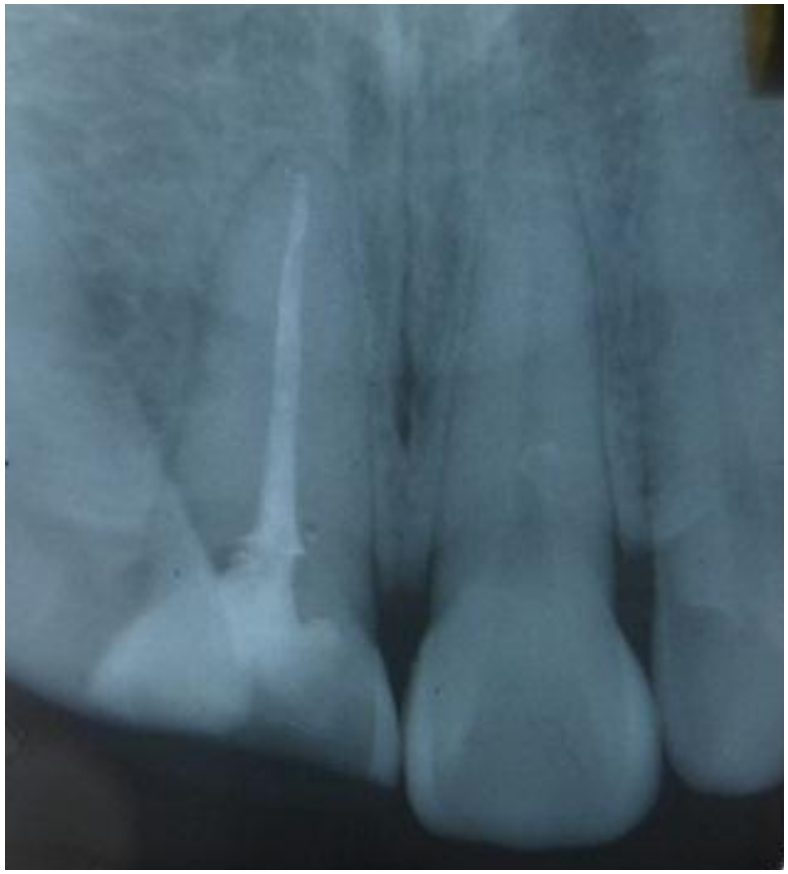

Gambar 4. Radiografis obturasi 11

Kunjungan kedua, 1 Oktober 2012. Kontrol satu minggu setelah perawatan saluran akar. Dilakukan pemeriksaan subjektif dan objektif pada gigi insisivus sentralis kanan maksila. Hasil pemeriksaan subjektif, tidak ada keluhan sakit pada pasien, hasil pemeriksaan objektif, tumpatan sementara masih baik, perkusi dan palpasi negatif. Perawatan dilanjutkan dengan pemasanganan pasak, pada kasus ini dilakukan pemasangan pasak fiber (fiber post denstply). Preparasi saluran pasak diawali dengan pengambilan gutta percha vmenggunakan Gates Glidden drill. Gutta percha diambil sepanjang $5 \mathrm{~mm}$ dari orifis, dilanjutkan preparasi pasak menggunakan Peeso reamer nomer 1,2,3. Sebelumnya sudah ditentukan panjang pasak yang masuk ke saluran akar yaitu 2/3 panjang akar, pada gigi ini saluran pasak $18 \mathrm{~mm}$ dari titik referensi dan guttap percha yang ditinggalkan 5,5 mm. Dilanjutkan preparasi saluran pasak menggunakan precision drill yang telah disediakan dalam kemasan pabrik. Selanjutnya adalah pemasangan pasak dengan menggunakan semen resin (Rely $X, 3 M$ ). Semen diaduk sesuai petunjuk pabrik dan dioleskan kedalam saluran akar menggunakan lentulo. Pasak fiber dioleskan semen resin dan dimasukkan kedalam saluran pasak (Gambar 5).

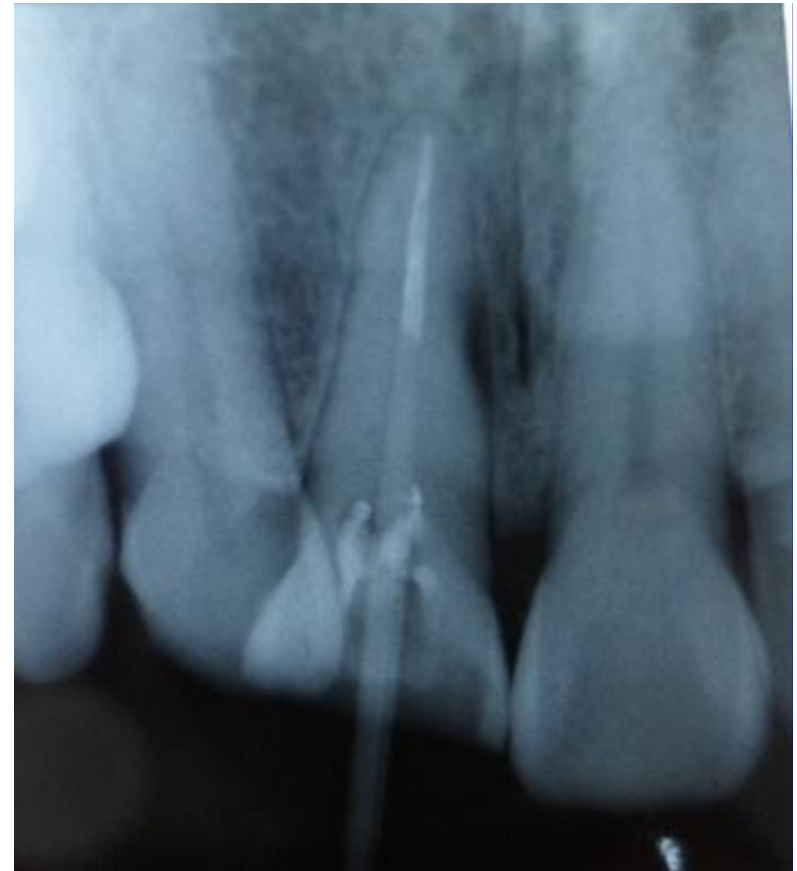

Gambar 5. Radiografis pasak fiber

Tahap berikutnya adalah preparasi gigi untuk pemasangan mahkota jaket. Preparasi pada gigi 11 dimulai dengan preparasi bagian insisal membuang restorasi lama dan membentuk sudut $45^{\circ}$ dengan wheel diamond bur. Preparasi bagian labial dengan flat-end diamond bur sejajar sumbu gigi yang dipreparasi. Preparasi proksimal menggunakan fissure tappered bur, bur diletakkan sejajar/paralel sehingga kemiringan yang akan terbentuk $6^{\circ}$. Singulum dupreparasi ke arah insisal dengan wheel diamond bur. Pada bagian servikal, preparasi pundak labial masuk ke subgingival $1 \mathrm{~mm}$ dengan fissure bur nomor 1. Tepi-tepi kavitas dibuat bevel, kemudian dilakukan pencetakan dengan bahan double impression untuk pembuatan mahkota porselin fusi metal.

Kunjungan ketiga, 8 Oktober 2012. Tahap pemasangan dimulai dengan menyiapkan mahkota jaket porselin fusi metal, kemudian dilakukan pengepasan mahkota jaket dengan melakukan cek oklusi menggunakan articulating paper. Setelah pasien merasa nyaman dengan mahkota jaket dapat dilakukan sementasi. Semen resin (Rely $X$, $3 \mathrm{M})$ diaplikasikan ke dalam mahkota jaket porselin dengan perlahan dan diinsersikan pada gigi dan sisasisa semen dibersihkan. Selanjutnya dilakukan cek oklusi dan artikulasi (gambar 6) 


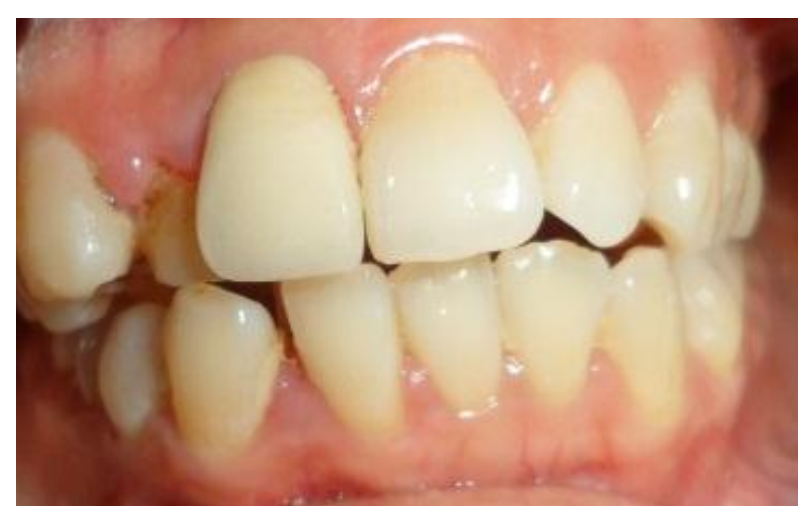

Gambar 6. Insersi mahkota jaket PFM

\section{PEMBAHASAN}

Perawatan saluran akar satu kunjungan pada beberapa kasus cukup menguntungkan diantaranya dapat menghemat waktu kunjungan, meminimalisir kontaminasi bakteri, tidak diperlukan medikasi intrakanal dan tumpatan sementara. Indikasi perawatan saluran akar satu kunjungan untuk kasus sebagai berikut : pulpa terbuka karena truma iatrogenik tanpa lesi periapikal, pulpitis ireversibel tanpa lesi periapikal, gigi nekrosis tanpa gejalagejala klinis dan lesi periapikal, gigi nekrosis dengan abses periapikal disertai fistula, bentuk saluran akar normal, saluran akar tunggal. Kontra indikasi untuk perawatan saluran akar satu kunjungan untuk kasus sebagai berikut: adanya rasa sakit pada gigi nekrosis tanpa disertai fistula untuk drainase, gigi dengan kelainan anatomis yang berat, gigi berakar banyak, periodontitis akut dengan rasa sakit yang parah saat perkusi. $^{7}$

Teknik preparasi saluran akar yang digunakan pada kasus ini adalah teknik step back, kelebihan teknik ini antara lain lebih efektif membersihkan saluran akar, mempermudah obturasi, pengisian lebih padat karena spreader dapat menjangkau sampai dekat dengan apeks sehingga mengurangi kebocoran apikal. Kerugian teknik ini antara lain membutuhkan waktu yang agak lama, ukuran saluran akar hasil preparasi biomekanik kecil pada aspek korona, dan pada proses obturasi rentan terjadinya gap baik vertikal maupun horisontal. ${ }^{49}$

Pada kasus ini digunakan bahan irigasi khlorheksidin $2 \%$ karena bahan ini mempunyai sifat antimikroba terhadap Enterococcus faecalis yang sering menyebabkan terjadinya kegagalan perawatan, selain itu digunakan bahan irigasi sodium hipoklorit $2,5 \%$. Sodium hipoklorit merupakan bahan irigasi mengandung klorin yang bersifat oksidator dan dianggap paling efektif karena bersifat lubrikan, melarutkan jaringan pulpa, pemutih dan antiseptik yang kuat. Selain bersifat bakterisidal, sodium hipoklorit juga virucidal. Konsentrasi $\mathrm{NaOCl}$ yang biasa digunakan adalah berkisar $0,5 \%$ - 5,25\%. EDTA $15 \%$ yang digunakan pada kasus ini merupakan agen khelasi yang efektif melunakkan dentin, derajat iritasi sedang, menghilangkan smear layer dan kombinasi dengan $\mathrm{NaOCl}$ akan menaikkan sifat antimikrobanya. Keberhasilan perawatan saluran akar satu kunjungan tergantung dari seleksi kasus yang tepat, ketrampilan operator serta ketaatan terhadap standar prinsip-prinsip endodontik. ${ }^{15}$

Gigi yang telah dirawat saluran akar seringkali hanya memiliki sedikit sisa jaringan keras gigi dibagian mahkota, menjadi lebih lemah atau rapuh dibandingkan gigi vital. Kelembaban telah berkurang dan secara klinis lebih mudah mengalami fraktur, sehingga membutuhkan pasak untuk menahan inti dan restorasi. Untuk itu diperlukan pasak dengan ukuran yang tepat masuk kedalam saluran akar untuk mendukung restorasi. Berdasarkan pertimbangan tersebut maka pasak yang bersifat pasif lebih diindikasikan untuk mencegah terjadinya penekanan dalam saluran akar sehingga resiko terjadinya fraktur akar dapat dihindari. ${ }^{6}$

Pada kasus ini digunakan pasak fiber karena pasak fiber merupakan pasak pasif, memiliki modulus elastisitas yang mendekati modulus elastisitas dentin sehingga dapat mencegah terjadinya fraktur akar. Pasak fiber yang digunakan termasuk pasak pasif berbentuk smooth tappered, sehingga sesuai dengan bentuk anatomi saluran akar dan mampu mempertahankan struktur gigi bagian apikal. Pasak fiber dapat mengurangi terjadinya fraktur akar dibandingkan pasak metal, karena pasak fiber menggunakan sistem bonding untuk sementasi, sedangkan pasak metal dipengaruhi bentuk oleh bentuk, konfigurasi permukaan pasak maupun jenis semen yang digunakan untuk sementasi. Pasak fiber juga memiliki keuntungan dari segi estetik, karena 
pasak ini memiliki warna yang sesuai dengan warna gigi, sehingga tidak menimbulkan bayangan keabuabuan pada gigi yang telah direstorasi. ${ }^{14}$

Mahkota jaket yang dipilih untuk gigi 11 adalah mahkota jaket porselin fusi metal dengan alasan bahan backing yang terbuat dari logam dapat menahan beban yang diterima sedangkan coping dari porselin dibutuhkan karena estetisnya baik, mengingat gigi yang direstorasi terletak pada bagian anterior sehingga estetis sangat dibutuhkan. ${ }^{13}$

\section{KESIMPULAN}

Berdasarkan pembahasan, dapat disim-pulkan bahwa perawatan saluran akar satu kunjungan dapat berhasil dilakukan bila didukung oleh kemampuan, pengetahuan, indikasi dan diagnosis kasus yang tepat serta ditunjang kerja yang asepsis sehingga kemungkinan terjadinya flare up dapat diatasi. Keberhasilan perawatan dapat mendukung pembuatan restorasi selanjutnya sehingga dapat mengembalikan fungsi gigi secara optimal. Penggunaan pasak fiber pada gigi pasca perawatan saluran akar memiliki banyak keuntungan dibandingkan pasak metal, serta didukung dengan restorasi mahkota porselin fusi metal.

\section{DAFTAR PUSTAKA}

1. Sluder Jr Tb. Clinical dental anatomy, histology, physiology and occlusion. In Studervant CM, Heymann HO, Studervant JR. The art and science of operative dentistry. Ed 2. St. Louis: The CV. Mosby Company; 1985.

2. Cheung WA. Review of the management of endodontically treted teeth: post, core and the final restoration. JADA. 2005; 136: 611-619.

3. Eccless JD, Green RM. Konservasi gigi (terj). Ed 2. Jakarta: Penerbit Universitas; 1994. H. 145-150.

4. Harty FJ. Endodonti klinis (terj). Ed 3. Jakarta: Hipokrates; 1993. H. 137-138.
5. Grossman. Ilmu endodontik dalam praktek (terj). Ed 11. Jakarta: Penerbit Buku Kedokteran EGC; 1995. H. 196-380.

6. Pitt Ford TR. Restorasi Gigi (terj). Ed 2. Jakarta: Penerbit Buku Kedokteran EGC; 1993.

7. Loeshe GM. Restoration of endodontically treated tooth: adhesion vs mechanical retention. in roulet $\mathrm{jf}$, degrange $m$ ( editor) adesion. the silent revolution in dentistry. Illionis: Quintessence Publishing Co, Inc; 2000. H. 329-355.

8. Annusavice KJ. Buku ajar ilmu kedokteran gigi (terj). Ed 10. Jakarta: Penerbit Buku kedokteran EGC; 2003.

9. Wwalton R, Torabinejad M. Prinsip dan praktek ilmu endodontik (terj). Ed 2. Jakarta: Penerbit Buku kedokteran EGC; 2008. H. 45-57.

10. Nisaan J, Dimitry Y, Assif D. The use of reinforced composit resin cement as compensation for reduced post length. J Prosthet Dent. 2001; 86: 304-308.

11. Rustin SA, Endang R. Perawatan saluran akar satu kunjungan pada gigi premolar kedua kiri mandibula dengan nekrosis pulpa disertai lesi periapikal. Maj Ked Gigi. 2007; 14 (1): 23-28.

12. Mannoci F, Innocenti, Ferrari M, Watson T. Confocal and scanning electron microscope study of teeth restored with fiber post, metal post and composite resins. J endo. 1999; 25:789-794.

13. Sorensen JA, Martinof JT. Clinically significant factors in ddowel design. J Prosthet Dent. 1984; 52: 28-35.

14. Peroz I, Blankenstein F, Lange KP \& Naumann M. Restoring Endodontically Treated Teeth With Post and Cores-Review, Quintessence Int 2005:36::737746.

15. Joko P, Ema M. Perawatan sluran akar satu kunjungan pada nekrosis pulpa disertai mahkota porselin fusimetal dengan pasak fiber. Maj Ked Gigi. 2011; 18 (1): 82-87.

16. Rosebstiel SF, Land MF, Fujimoto J. Contemporary fixed prosthodontics. Ed 3. St Louis. Missouri: Mosby Elsevier; 2001. 